\title{
Kontribusi Usaha Ternak Ayam Ras Pedaging terhadap Pendapatan Petani Di Desa Sungai Malang Kecamatan Amuntai Tengah Kabupaten Hulu Sungai Utara
}

\section{(Contribution of Chicken Livestock toward Farmer Income in Sungai Malang Village District of Central Amuntai Hulu Sungai Utara Regency)}

\author{
Purna Kusumayana ${ }^{1)}$ \& Rezqi Hatimah \\ Program Studi Agribisnis, Sekolah Tinggi Ilmu Pertanian Amuntai \\ 1)kusumayanapurna@yahoo.com
}

\begin{abstract}
ABSTRAK
Tujuan dari penelitian ini adalah mengetahui (i) struktur biaya, penerimaan, pendapatan usaha ternak ayam ras pedaging di Desa Sungai Malang Kecamatan Amuntai Tengah, (ii) struktur biaya, penerimaan, pendapatan usahatani padi di Desa Sungai Malang Kecamatan Amuntai Tenga,. (iii) besarnya kontribusi usaha ternak ayam ras pedaging terhadap pendapatan petani di Desa Sungai Malang Kecamatan Amuntai Tengah, (iv) permasalahan yang dihadapi peternak dalam pengelolaan usaha peternakan ayam ras pedaging. Penelitian ini dilakukan di Desa Sungai Malang, Kecamatan Amuntai Tengah, Kabupaten Hulu Sungai Utara dari bulan Maret - Juni 2011. Menggunakan metode sensus pada 42 responden petani. Hasil penelitian menyebutkan bahwa total biaya dari usaha ternak ayam di Desa Sungai Malang Kecamatan Amuntai Tengah adalah Rp 10.375.697,-, dengan pendapatan sekitar Rp 16.960.114,-/kg dan penghasilan sebesar Rp 57.105.886,-. Besarnya pendapatan usahatani padi di Desa Sungai Malang Kecamatan Amuntai Tengah adalah Rp 2.662.504,-, dengan pendapatan sekitar Rp 5.317.500,-/blek dan penghasilan setara Rp 3.800.667,-. Kontribusi usaha ternak ayam terhadap pendapatan adalah $91 \%$ dari total pendapatan peternak.
\end{abstract}

Kata kunci: Ternak, ayam, pendapatan, peternak, kontribusi.

\section{ABSTRACT}

Destination from this observation is understand (i) structure costs, revenue, income attempt ranch chicken in Sungai Malang village Isaland Amuntai Tengah, (ii) structure costs, revenue, income attempt rice in Sungai Malang village Kecamatan Amuntai Tengah, (iii) contribution big attempt chicken to income attempt rich in Sungai Malang Village Amuntai Tengah Distric,. (iv) problem ascertain poltry in administer attempt chicken. This research was conducted in Sungai Malang Village Amuntai Tengah District Hulu Sungai Utara Regency from March-June 2011. Used sensus method at 42 farmer respondents. The results referred that total cost from chicken livestock in Sungai Malang Village District of Central Amuntai was Rp 10.375.697,-, with revenue about Rp 16.960.114,-/kg and income equal to Rp 57.105.886,-. Total costs of rice in Sungai Malang village Central Amuntai District was Rp 2.662.504,-, with revenue about $R p$ 5.317.500,-/blek and income equal is Rp 3.800.667,-. Contribution chicken livestock to income was $91 \%$ from total income occur farmer.

Keywords : Chicken, livestock, farmer, income, contribution.

\section{PENDAHULUAN}

Sepanjang 2008 lalu ditengah tekanan yang mendera berbagai sektor industri di dalam negeri, sektor peternakan unggas tetap mampu bertahan. Industri peternakan di Indonesia menunjukan kinerja yang cukup bagus. Bahkan dalam tahun 2009 ketika krisis global yang belum berlalu ketika terjadi penurunan daya beli yang kemudian mendorong substitusi pangan ke produk unggas, industri perunggasan masih mampu bertahan. Produk unggas yang tetap bertahan di tengah krisis adalah ayam dan telur yang termasuk sebagai protein hewani yang harganya relatif murah dibandingkan dengan daging sapi (Uripsantoso, 2010).

Pertumbuhan populasi ternak yang dikembangan Pemerintah Propinsi pada tahun 2006-2009 rata-rata mengalami kenaikan. Pada tahun 2006 tercatat ada sekitar 20.624.128 ekor populasi ayam ras 
pedaging begitu pula pada tahun 2007 terdapat 21.534 .508 ekor populasi ayam ras pedaging sampai pada tahun 2009 jumlah populasi meningkat drastis.

Pada tahun 2006-2009 di Kabupaten Hulu Sungai Utara jelas terlihat peningkatan yang terus menerus, pada tahun 2006 terdapat 677.743 ekor populasi ayam ras pedaging. Selanjutnya ditahun 2007 peningkatan jumlah populasi juga terjadi menjadi 679.877 ekor. Begitupula di tahun 2008 bertambah menjadi 685.835 ekor populasi ayam ras pedaging. Sampai pada tahun 2009 yakni sebanyak 703.591 ekor populasi ayam ras pedaging terdapat di Kabupaten Hulu Sungai Utara.

Kecamatan Amuntai Tengah merupakan wilayah yang banyak mengelola ternak ayam ras pedaging. Dimana tingkat populasinya terus meningkat dari tahun ke tahun. Pada tahun 2007 di Kecamatan Amuntai Tengah hanya terdapat 259.565 ekor ayam ras pedaging meningkat di tahun 2009 menjadi 268.618 ekor dan kecamatan yang menjadi daerah terendah ialah Babirik dengan nilai 5.158 ekor ayam ras pedaging pada tahun 2007 selanjutnya ditahun 2009 mengalami kenaikan menjadi 5.338 ekor namun masih jauh perbandingannya dengan Kecamatan Amuntai Tengah.

Pendapatan petani dapat berasal dari usahatani dan luar usahatani. Pendapatan yang diperoleh petani akan mendorong petani untuk dapat mengalokasikannya dalam berbagai kegunaan seperti untukbiaya produksi selanjutnya, tanggungan dan pengeluaran lain untuk memenuhi keperluan keluarga. Alasan utama dalam melaksanakan penelitian pada sektor peternakan untuk mengetahui besarnya kontribusi dari usaha ternak ayam ras pedaging yang tujuannya untuk meningkatkan pendapatan petani yang ada di Desa Sungai Malang. Pendapatan petani yang semula hanya dari berusahatani padi dan non usahatani apakah meningkat dengan usaha ternak ayam ras pedaging.

Tujuan dari penelitian ini yaitu; (1) Mengetahui biaya, penerimaan, penda-patan cabang usaha peternakan ras ayam pedaging, (2) Mengetahui biaya, peneri-maan, pendapatan cabang usaha selain peternakan ras ayam pedaging, dan (3) Mengetahui berapa besar kontribusi usaha peternaka ayam ras pedaging terhadap pendapatan petani, (4) Mengetahui permasalahan yang dihadapi dalam mengelola usaha peternak ayam ras pedaging.

\section{METODE PENELITIAN}

\section{Tempat dan Waktu Penelitian}

Penelitian dilaksanakan di Desa Sungai Malang Kecamatan Amuntai Tengah. Waktu penelitian bulan Maret - Juni 2011, dari tahap persiapan, pengumpulan data, pengolahan data, sampai penulisan laporan.

\section{Jenis dan Sumber Data}

Data yang dikumpulkan berupa data primer dan data sekunder. Data primer diperoleh melalui wawancara menggunakan daftar pertanyaan. Sedangkan data sekunder diperoleh dari dinas instansi yang berhubungan dengan penelitian. Pengumpulan data meng-gunakan metode sensus dengan responden semua anggota populasi yaakni semua petani yang berusaha ternak ayam ras pedaging sekitar 42 orang peternak ayam ras pedaging yang ada di Desa Sungai Malang Kecamatan Amuntai Tengah Kabupaten Hulu Sungai Utara.

\section{Analisa Data}

\section{Struktur Biaya dan Pendapatan Ternak Ayam Ras Pedaging.}

Perhitungan biaya total usaha ternak ayam ras pedaging dinyatakan dengan rumus sebagai berikut:

Dimana:

$$
\text { TC1 }=\mathrm{TCi}+\mathrm{TCe}
$$

$$
\begin{aligned}
\mathrm{TC} 1 & =\text { biaya total cabang usaha } \\
& \text { ternak ayam ras pedaging } \\
\mathrm{TCi} & =\text { biaya total implisit } \\
\mathrm{TCe} & =\text { biaya total eksplisit }
\end{aligned}
$$

Biaya penyusutan barang dalam usaha ternak ayam ras pedaging dinyatakan dengan rumus sebagai berikut:

Dimana:

$$
\mathrm{Du}=\frac{\mathbf{N a} \cdot \text { Uunit }}{\text { UEB }}
$$

$\mathrm{Du} \quad=$ besarnya nilai penyusutan 
Purna Kusumayana \& Rezqi Hatimah, Kontribusi usaha ternak ayam...

barang modal tetap yang dipergunakan untuk usaha ternak unggas tertentu selama masa produksi (tahun)

$\mathrm{N} \quad=$ besarnya nilai awal barang modal tetap yang sama dengan har-ga pengadaan atau harga pembelian $(\mathrm{Rp})$

$\sum$ Unit $=$ jumlah Unit

UEB = usia ekonomis barang

Penerimaan usaha ternak ayam ras pedaging dapat dinyatakan dengan rumus sebagai berikut:

$$
\mathbf{T R 1}=\mathbf{Y} . \mathbf{P y}
$$

Dimana:

$$
\begin{aligned}
& \mathrm{Y}=\text { Jumlah output } \\
& \mathrm{Py}=\text { Harga jual output }
\end{aligned}
$$

Pendapatan usaha ternak ayam ras pedaging dapat dinyatakan dengan rumus sebagai berikut:

$$
\text { I1 = TR1 - TCe }
$$

Dimana:

$$
\begin{aligned}
\mathrm{TR} 1 & =\begin{array}{c}
\text { Penerimaan usaha ternak } \\
\text { ayam ras pedaging }
\end{array} \\
\mathrm{TCe} & =\text { Biaya total eksplisit }
\end{aligned}
$$

\section{Struktur Biaya dan Pendapatan} Usahatani Padi.

Perhitungan biaya total usahatani padi dinyatakan dengan rumus sebagai berikut:

Dimana:

$$
\mathrm{TC2}=\mathrm{TCi}+\mathrm{TCe}
$$

$$
\begin{aligned}
\text { TC2 } & \text { biaya total total usahatani } \\
& \text { padi } \\
\mathrm{TCi} & =\text { biaya total implisit } \\
\mathrm{TCe} & =\text { biaya total eksplisit }
\end{aligned}
$$$$
\text { Penghitungan biaya penyusutan }
$$
menggunakan rumus yang sama dengan biayaa penyusutan usaha ternak ayam ras pedaging.

Besarnya penerimaan usahatani padi dinyatakan dengan rumus sebagai berikut:

$$
\mathbf{T R 2}=\mathbf{Y} . \mathbf{P y}
$$

Dimana:

$$
\begin{aligned}
& \mathrm{TR} 2=\text { penerimaan total } \\
& \mathrm{Y}=\text { jumlah output } \\
& \mathrm{Py}=\text { harga jual output }
\end{aligned}
$$

Rumus yang digunakan untuk menghitung pendapatan usahatani padi adalah sebagai berikut:
Dimana:

$$
\text { I2 }=\text { TR2 }- \text { TCe }
$$

I2 = pendapatan usahatani padi

$\mathrm{TR}=$ penerimaan total

$\mathrm{TCe}=$ biaya total eksplisit

Untuk menghitung pendapatan usahatani secara keseluruhan digunakan rumus:

$$
\mathbf{I} \mathbf{u}=\mathbf{I} 1+\mathbf{I} 2
$$

Dimana:

$$
\begin{aligned}
\mathrm{Iu}= & \text { pendapatan usahatani secara } \\
& \text { keseluruhan }(\mathrm{Rp}) \\
\mathrm{I} 1= & \text { pendapatan usaha ternak ayam } \\
& \text { ras pedaging } \\
\mathrm{I} 2= & \text { pendapatan usahatani padi }
\end{aligned}
$$

Untuk menghitung pendapatan non usahatani digunakan rumus:

Dimana:

$$
\mathbf{I n u}=\sum \mathbf{N I}
$$

$$
\begin{gathered}
\text { Inu = pendapatan Non Usahatani } \\
\text { selama satu periode }(\mathrm{Rp}) \\
\mathrm{NI}= \\
\text { pendapatan yang diperoleh } \\
\text { petani dari kegiatan Non } \\
\text { usahatani ke-i }
\end{gathered}
$$

Untuk menghitung pendapatan total petani adalah digunakan rumus:

Dimana:

$$
\mathbf{I}=\mathbf{I u}+\mathbf{I n u}
$$

$$
\begin{aligned}
& \mathrm{I}=\text { pendapatan total petani } \\
& \mathrm{Iu}=\text { pendapatan usahatani } \\
& \mathrm{Inu}=\text { pendapatan non usahatani } \\
& \text { Untuk menghitung kontribusi }
\end{aligned}
$$
digunakan rumus:

$$
\mathrm{K} 1=\frac{\mathrm{I} 1 \mathrm{x}}{\mathrm{I}} 100 \%
$$

Dimana:

$$
\begin{aligned}
\mathrm{K} 1= & \text { kontribusi usaha ternak ayam } \\
& \text { ras pedaging } \\
\mathrm{I} 1= & \text { pendapatan ayam ras } \\
& \text { pedaging } \\
\mathrm{I}= & \text { pendapatan total }
\end{aligned}
$$

HASIL DAN PEMBAHASAN

Struktur Biaya dan Pendapatan Usaha Ternak Ayam Ras Pedaging

Biaya. 
Rawa Sains: Jurnal Sains STIPER Amuntai, Desember 2011, 1(1), 30-38.

Komponen biaya yang dihitung dan dianalisis pada usaha ternak Ayam ras pedaging meliputi biaya eksplisit dan biaya implisit.

\section{Biaya Eksplisit.}

Biaya eksplisit merupakan biaya yang benar-benar dikeluarkan secara nyata. Biaya dalam pelaksanaan ternak ayam ras pedaging di Desa Sungai Malang adalah biaya penyusutan alat dan perlengkapan, pakan, bibit, obat-obatan, tenaga kerja luar keluarga (TKLK), air bersih dan listrik. Berdasarkan Tabel 1. diketahui Biaya eksplisit yang paling besar adalah biaya pakan dengan biaya ratarata sebesar $\mathrm{Rp}$ 6,678,571 dengan persentase $68 \%$ sedangan biaya yang paling terendah adalah biaya listrik dengan biaya rata-rata sebesar Rp 26.429 dengan persentase 0,2\%.

Tabel 1. Rata-rata biaya eksplisit selama satu tahun usaha ternak Ayam Ras Pedaging di Desa Sungai Malang

\begin{tabular}{clcc}
\hline No. & \multicolumn{1}{c}{ Komponen Biaya } & Biaya $(\mathrm{Rp})$ & Persentase $(\%)$ \\
\hline 1. & Bibit & $1,583,333$ & 16,12 \\
2. & Pakan & $6,678,571$ & 68 \\
3. & Obat-obatan & 62,143 & 0,63 \\
4. & TKLK & 92,619 & 0,94 \\
5. & Penyusutan alat dan perlengkapan & $1,345,533$ & 13,70 \\
6. & Air & 33,250 & 0,34 \\
7. & Listrik & 26,429 & 0,27 \\
\hline & & $9,821,879$ & 100 \\
\hline
\end{tabular}

\section{Biaya Implisit.}

Biaya implisit merupakan biaya yang tidak benar-benar dikeluarkan secara nyata oleh peternak ayam ras pedaging tetapi tetap diperhitungkan secara nyata. Biaya implisit pada usaha ternak ayam ras pedaging di Desa Sungai Malang adalah tenaga kerja dalam keluarga (TKDK), biaya bunga modal sendiri.

Tabel 2. Rata-rata biaya implisit usaha ternak Ayam Ras Pedaging di Desa Sungai Malang Selama Satu Tahun

\begin{tabular}{clcc}
\hline No. & Komponen Biaya & Biaya (Rp) & Persentase $(\%)$ \\
\hline 1. & TKDK & 357,381 & 64,53 \\
2. & Bunga Modal & 196,438 & 35,47 \\
\hline & Jumlah & 553,819 & 100
\end{tabular}

Berdasarkan Tabel 2. diketahui Biaya implisit yang paling besar adalah biaya tenaga kerja dalam keluarga (TKDK) dengan biaya rata-rata sebesar $\mathrm{Rp} 357.381$ dengan persentase $64,53 \%$ sedangan biaya yang paling terendah adalah biaya bunga modal dengan biaya rata-rata sebesar Rp 196.438 dengan persentase $35,47 \%$.

\section{Biaya Total (Total Cost).}

Biaya total $(\mathrm{TCe}+\mathrm{TCi})$ merupakan penjumlahan antara biaya eksplisit total dengan biaya implisit total. 
Purna Kusumayana \& Rezqi Hatimah, Kontribusi usaha ternak ayam...

Tabel 3. Rata-rata biaya total usaha ternak Ayam ras pedaging di Desa Sungai Malang Selama Satu Tahun

\begin{tabular}{rrrrrr}
\hline No. & $\begin{array}{c}\text { Biaya } \\
\text { Implisit }\end{array}$ & $\begin{array}{c}\text { Biaya } \\
\text { Rata-rata (Rp) }\end{array}$ & \multicolumn{1}{c}{$\begin{array}{c}\text { Biaya } \\
\text { Eksplisit }\end{array}$} & $\begin{array}{c}\text { Biaya } \\
\text { Rata-rata (Rp) }\end{array}$ & \multicolumn{1}{c}{$\begin{array}{c}\text { Total Biaya } \\
(\mathrm{Rp})\end{array}$} \\
\hline 1. & TKDK & 357,381 & Saprodi & 8.324 .047 & 8.681 .428 \\
2. & Bunga Modal & 196,438 & TKLK & 92,619 & 289.057 \\
3. & & Penyusutan & $1,345,533$ & $1,345,533$ \\
4. & & Air & 33,250 & 33,250 \\
5. & & Listrik & 26,429 & 26,429 \\
\hline & & & & $9,821,879$ & 10.375 .697 \\
\hline
\end{tabular}

Berdasarkan Tabel 3 diketahui bahwa biaya total implisit dan eksplisit usaha ternak ayam ras pedaging dengan rata-rata total biaya $\mathrm{Rp}$ 10.375.697 Biaya rata-rata paling besar dikeluarkan adalah biaya eksplisit yaitu sebesar Rp 9.821.879 sedangkan untuk biaya terendah adalah biaya implisit dengan biaya rata-rata sebesar $\mathrm{Rp} \quad 553.819 \quad$ Ini menunjukkan bahwa usaha peternakan ayam ras pedaging biaya yang paling dominan adalah biaya eksplisitnya.

\section{Penerimaan}

Rata-rata jumlah produksi usaha ternak ayam ras pedaging adalah 633.333 ekor per periode dengan rata-rata jual sebesar Rp. 16.500 per Kg per periode. Dari perhitungan dapat diperoleh penerimaan rata-rata yang diterima peternak ayam ras pedaging pada saat satu kali produksi adalah sebesar Rp16,960,114 per produksi (Tabel 4).

Tabel 4. Rata-rata ppenerimaan usaha ternak Ayam ras pedaging di Desa Sungai Malang Selama Satu Tahun

\begin{tabular}{|c|c|c|c|}
\hline No. & Produksi & Harga Per Kg & Total Penerimaan \\
\hline 1. & 633.333 Ekor & Rp.16.500 & $16,960,114$ \\
\hline
\end{tabular}

\section{Pendapatan}

Pendapatan usahatani adalah besarnya penerimaan dikurangi dengan biaya eksplisit. Pendapatan rata-rata petani ayam ras pedaging di Desa Sungai Malang (Tabel 5.).

Berdasarkan Berdasarkan hasil perhitungan dapat diperoleh rata-rata penerimaan sebesar Rp. 16,960,114 per produksi dan rata-rata biaya eksplisit sebesar Rp. 9,821,879. Sedangkan rata-rata pendapatan peternak responden dalam satu tahun adalah sebesar Rp. 57,105,886 .

Tabel 5. Rata-rata pendapatan usaha ternak Ayam ras pedaging di Desa Sungai Malang Selama Satu Tahun

\begin{tabular}{ccccc}
\hline No. & Penerimaan & Biaya Eksplisit & \multicolumn{2}{c}{ Total Pendapatan } \\
\hline 1. & Rp. $16,960,114$ & Rp. $9,821,879$ & Rp & $57,105,886$ \\
\hline
\end{tabular}


Rawa Sains: Jurnal Sains STIPER Amuntai, Desember 2011, 1(1), 30-38.

\section{Struktur Biaya dan Pendapatan Usahatani Padi}

Biaya. Biaya pada dasarnya adalah nilai dari semua input bagi terselenggaranya kegiatan dan proses produksi usaha sejak awal sampai dengan diperolehnya output atau hasil yang diselenggarakan. Komponen biaya yang dihitung dan dianalisis pada usahatani padi meliputi biaya eksplisit dan biaya implisit.

Biaya Eksplisit. Biaya eksplisit merupakan biaya yang benar-benar dikeluarkan secara nyata. Biaya dalam pelaksanaan pertanian di Desa Sungai Malang adalah bibit, pupuk, biaya penyusutan perlengkapan, tenaga kerja luar keluarga (TKLK).

Tabel 6. Rata-rata biaya eksplisit usahatani Padi di Desa Sungai Malang Selama Satu Tahun

\begin{tabular}{|c|c|c|c|}
\hline No. & Komponen Biaya & Biaya $(\mathrm{Rp})$ & Persentase (Rp) \\
\hline 1. & Bibit & 554.167 & 36,8 \\
\hline 2. & Pupuk & 2.000 & 0,1 \\
\hline 3. & TKLK & 792.810 & 53,1 \\
\hline 4. & Penyusutan perlengkapan & 167.857 & 10 \\
\hline & Jumlah & 1.516 .833 & 100 \\
\hline
\end{tabular}

Biaya eksplisit yang paling besar adalah biaya TKLK dengan biaya rata-rata sebesar Rp 792.810 dengan persentase 53,1 $\%$ sedangan biaya yang paling terendah adalah biaya pupuk dengan biaya rata-rata sebesar Rp 2.000 dengan persentase $0,1 \%$.

Biaya Implisit. Biaya implisit merupakan biaya yang tidak dikeluarkan secara nyata oleh petani tetapi tetap diperhitungkan secara nyata. Biaya implisit pada usahatani di Desa Sungai Malang adalah tenaga kerja dalam keluarga (TKDK), biaya bunga modal sendiri. Biaya implisit yang paling besar adalah biaya tenaga kerja dalam keluarga (TKDK) rata-rata sebesar Rp 1.117.571 dengan persentase $97 \%$, sedangan biaya yang paling terendah adalah biaya bunga modal dengan biaya rata-rata sebesar Rp 28.099 dengan persentase $3 \%$.

Tabel 7. Rata-rata biaya implisit usahatani Padi di Desa Sungai Malang Selama Satu Tahun

\begin{tabular}{clcc}
\hline No. & Komponen Biaya & Besar Biaya $(\mathrm{Rp})$ & Persentase $(\%)$ \\
\hline 1. & TKDK & 1.117 .571 & 97 \\
2. & Bunga Modal & 28.099 & 3 \\
\hline & Jumlah & 1.145 .670 & 100 \\
\hline
\end{tabular}

Biaya Total (Total Cost). Biaya total ( $\mathrm{TCe}+\mathrm{TCi})$ merupakan penjumlahan antara biaya ekspisit total dengan biaya implisit total. Berdasarkan Tabel 8. diketahui bahwa biaya total implisit dan eksplisit usahatani padi dengan rata-rata total biaya $\mathrm{Rp}$ 2.662.504. Biaya rata-rata paling besar dikeluarkan adalah biaya eksplisit yaitu sebesar Rp 1.516.833 sedangkan untuk biaya terendah adalah biaya implisit dengan biaya rata-rata sebesar $\mathrm{Rp} \quad 1.145 .670$ Ini menunjukkan bahwa pada usahatani padi biaya yang paling dominan adalah biaya eksplisitnya. 
Purna Kusumayana \& Rezqi Hatimah, Kontribusi usaha ternak ayam...

Tabel 8. Rata-rata biaya total usahatani Padi di Desa Sungai Malang Selama Satu Tahun

\begin{tabular}{llrlrr}
\hline No. & $\begin{array}{c}\text { Biaya } \\
\text { Implisit }\end{array}$ & $\begin{array}{c}\text { Biaya } \\
\text { Rata }- \text { rata } \\
(\mathrm{Rp})\end{array}$ & $\begin{array}{c}\text { Biaya } \\
\text { Eksplisit } \\
(\mathrm{Rp})\end{array}$ & $\begin{array}{c}\text { Biaya } \\
\text { Rata }- \text { rata } \\
(\mathrm{Rp})\end{array}$ & $\begin{array}{c}\text { Total Biaya } \\
(\mathrm{Rp})\end{array}$ \\
\hline 1. & TKDK & 1.117 .571 & Saprodi & 556.167 & 1.607 .600 \\
2. & Bunga Modal & 28.099 & TKLK & 792.810 & 834.006 \\
3. & & & Penyusutan & 167.875 & 158.455 \\
\hline & Jumlah & 1.145 .670 & & 1.516 .833 & 2.662 .504 \\
\hline
\end{tabular}

\section{Penerimaan}

Penerimaan usahatani adalah perkalian antara produksi yang diperoleh dengan harga jual yang berlaku saat ini (saat penelitian berlangsung). Rara-rata jumlah produksi

usahatani padi adalah 94 blek dengan ratarata jual sebesar Rp. 45.000 per blek. Penerimaan rata-rata usaha ternak ayam ras pedaging dapat dilihat pada Tabel 9.

Tabel 9. Rata-rata penerimaan usahatani Padi di Desa Sungai Malang Selama Satu Tahun.

\begin{tabular}{cccc}
\hline No. & Produksi & Harga Per Blek & Total Penerimaan \\
\hline 1. & 118 blek & Rp 45.000 & Rp 5.317.500 \\
\hline
\end{tabular}

Berdasarkan Tabel 9 diketahui bahwa dari hasil perhitungan rata-rata jumlah produksi padi sebesar 118 blek dan harga per blek sebesar Rp 45.000,-. Dari perhitungan dapat diperoleh penerimaan rata-rata yang diterima petani padi pada saat adalah sebesar Rp.5.317.500,-.

\section{Pendapatan}

Pendapatan usahatani adalah besarnya penerimaan dikurangi dengan biaya eksplisit.
Pendapatan rata-rata petani pada usahatani padi di Desa Sungai Malang dapat dilihat pada Tabel 10.

Hasil perhitungan diperoleh rata-rata penerimaan sebesar Rp 5.317.500 produksi per blek dan rata - rata biaya eksplisit sebesar Rp 1.516.833. Dari hasil perhitungan diperoleh rata-rata pendapatan petani responden adalah sebesar $\mathrm{Rp} 3.800 .667,-$.

Tabel 10. Rata-rata pendapatan usahatani Padi di Desa Sungai Malang Selama Satu Tahun

\begin{tabular}{cccc}
\hline No. & Penerimaan & Biaya Eksplisit & Total Pendapatan \\
\hline 1. & Rp 5.317.500 & Rp 1.516.833 & Rp 3.800.667 \\
\hline
\end{tabular}

\section{Total Pendapatan Usahatani}

Pendapatan keseluruhan usahatani merupakan penjumlahan dari pendapatan usaha ternak ayam ras pedaging dengan ushatani padi. Pendapatan keseluruhan usahatani dapat dilihat pada tabel 11 .
Pendapatan terbesar adalah dari usaha ternak ayam ras pedaging yaitu $\mathrm{Rp} 57,105,886$ dengan persentase $93,75 \%$ dan pendapatan terendah dari usahatani padi yaitu sebesar Rp $3,800,667$ dengan persentase $6,25 \%$. 
Rawa Sains: Jurnal Sains STIPER Amuntai, Desember 2011, 1(1), 30-38.

Tabel 11. Rata-rata pendapatan keseluruhan usahatani di Desa Sungai Malang Kecamatan Amuntai Tengah

\begin{tabular}{cccc}
\hline No. & \multicolumn{1}{c}{ Cabang Usahatani } & Pendapatan (Rp) & Persentase (\%) \\
\hline 1. & Usaha ternak ayam ras pedaging & $57,105,886$ & 93,75 \\
2. & Usahatani padi & $3,800,667$ & 6,25 \\
\hline & Jumlah & $60,906,552$ & 100 \\
\hline
\end{tabular}

Pendapatan non usahatani merupakan pendapatan yang diperoleh diluar dari pendapatan usahatani adalah pengrajin purun, buruh, tukang beca, tukang bangunan dan ojek, Berdasarkan hasil penelitian, ratarata pendapatan non usahatani sebesar $\mathrm{Rp}$. 1.753.452,-.

\section{Total Pendapatan Petani}

Pendapatan total petani merupakan pendapatan yang diperoleh dari seluruh pendapatan baik usahatani maupun non usahatani, untuk mengetahui pendapatan total petani pada tabel 12. Dilihat dari tabel tersebut ternyata persentase terbesar berasal dari pendapatan cabang usaha ternak ayam ras pedaging yaitu sebesar 91,14\% dan persentase terendah berasal dari cabang non usahatani sebesar $2,80 \%$.

Tabel 12. Rata-rata Pendapatan Total Peternak di Desa Sungai Malang Kecamatan Amuntai Tengah

\begin{tabular}{clcc}
\hline No. & \multicolumn{1}{c}{ Cabang Usaha } & $\begin{array}{c}\text { Pendapatan } \\
(\mathrm{Rp})\end{array}$ & Persentase (\%) \\
\hline 1. & Usaha ternak ayam ras pedaging & $57,105,886$ & 91,14 \\
2. & Usahatani padi & $3,800,667$ & 6,07 \\
3. & Non usahatani & $1,753,452$ & 2,80 \\
\hline & Jumlah & $62,660,005$ & 100 \\
\hline
\end{tabular}

Kontribusi Usaha Ternak Ayam Ras Pedaging

Kontribusi usaha ternak ayam ras pedaging merupakan nilai sumbangsih pendapatan usaha ternak ayam ras pedaging terhadap total pendapatan petani adalah sebesar $91 \%$., Hasil ini dapat dilihat pada tabel 13.

Tabel 13. Rata-rata Kontribusi Usaha Ternak Ayam Ras Pedaging Terhadap Pendapatan Petani di Desa Sungai Malang Kecamatan Amuntai Tengah

\begin{tabular}{cccccc}
\hline No. & \multicolumn{2}{c}{$\begin{array}{c}\text { Pendapatan Total } \\
\text { Petani }\end{array}$} & \multicolumn{2}{c}{$\begin{array}{c}\text { Pendapatan Usaha Ternak } \\
\text { ayam Ras Pedaging }\end{array}$} & Kontribusi \\
\hline 1. & $\mathrm{Rp}$ & $62,660,005$ & $\mathrm{Rp}$ & $57,105,886$ & $91 \%$ \\
\hline
\end{tabular}


Purna Kusumayana \& Rezqi Hatimah, Kontribusi usaha ternak ayam...

\section{KESIMPULAN}

Total biaya dari usaha ternak ayam ras pedaging di Desa Sungai Malang Kecamatan Amuntai Tengah adalah sebesar $\mathrm{Rp}$ 10.375.697,-, penerimaan sebesar $\mathrm{Rp}$ 16.960.114,-/kg. dan pendapatan sebesar Rp 57.105.886,-. Besarnya biaya total usahatani padi di Desa Sungai Malang Kecamatan Amuntai Tengah adalah Rp 2.662.504,-, penerimaan sebesar Rp 5.317.500,-/blek. dan pendapatan sebesar 3.800.667,-.

Kontribusi usaha ternak ayam ras pedaging terhadap pendapatan petani di daerah penelitian adalah sebesar $91 \%$ dari total pendapatan petani.

\section{DAFTAR PUSTAKA}

Badan Pusat Statistik. 2009. Kabupaten Hulu Sungai Utara Dalam Angka.

Badan Pusat Statistik. 2009. Kecamatan Amuntai Tengah Dalam Angka. Badan Pusat Statistik Kabupaten Hulu Sungai Utara. Amuntai.

Dinas Peternakan. 2004. Booklet Ayam Ras Pedaging. Dinas Peternakan Hulu Sungai Utara. Amuntai.

Dinas Peternakan Kabupaten Hulu Sungai Utara. 2005. Statistik Peternakan. Amuntai.

Dinas Peternakan Kabupaten Hulu Sungai Utara. 2008. Laporan Tahunan Pemerintah Kabupaten Hulu Sungai Utara.

Dinas Peternakan Kabupaten Hulu Sungai Utara. 2009. Laporan Tahunan Pemerintah Kabupaten Hulu Sungai Utara.

Kasim, Syarifuddin. 1997. Menghitung Praktis Keuntungan dan Pendapatan Usahatani. Fakultas Pertanian Universitas Lambung Mangkurat. Banjarbaru.
Uripsantoso. 2010. Beternak Ayam Ras Pedaging. $\quad$ http://wordpress.com/. dasasila peternakan. Diakses tanggal 14 Februari 2011.

Soekartawi. 2006. Analisis Usaha Tani. Penerbit Universitas Indonesia. 